\title{
Birmingham Medical Research Expeditionary Society 1977 Expedition: Serum and urine proteins during a high altitude trek
}

\author{
A. R. BRADWELL \\ M.B., Ch.B., M.R.C.P. \\ Immunodiagnostic Research Laboratory, Department of Immunology, \\ The Medical School, Birmingham B15 2TJ
}

\begin{abstract}
Summary
Serum and urine proteins were measured daily in 17 subjects undertaking a typical high altitude Himalayan trek. Marked changes occurred in a variety of serum proteins as a result of plasma volume alterations and 'stress'. There was only a sporadic increase in proteinuria. None of the changes was related to the development of acute mountain sickness.
\end{abstract}

\section{Introduction}

Exposure to high altitude is known to alter the concentrations of several serum proteins. Rennie et al. (1972) measured the immunoglobulins IgG, IgA and IgM plus albumin and $\alpha_{2}$-macroglobulin. All these proteins increased significantly in concentration. Hannon, Chinn and Shields (1969) showed that the concentrations of the serum fractions measured by electrophoresis also altered markedly in concentration and suggested that some of these changes could be accounted for by changes in the hydration of the subjects, or by changes in plasma volume.

'Stress' also alters the concentration of many serum proteins. This can be demonstrated in patients undergoing surgical procedure, such as inguinal hernia repair. Within hours of the operation the serum concentration of $\mathrm{C}$-reactive protein (mol. wt 200000 - unknown function) has increased several fold and, by 3 days, many other proteins, including orosomucoid (mol. wt 44100 - unknown function) and haptoglobin (mol. wt approx. 100000 - binds haemoglobin) have dramatically increased in concentration. The mechanisms mediating these changes are unknown but the changes are so reliable that the proteins are of use in monitoring patients with cancer (Milford Ward et al., 1977; Bradwell et al., 1976) and rheumatoid arthritis (McConkey, Crockson and Crockson, 1972). The stress of altitude or acute mountain sickness (AMS) might also affect the concentrations of the proteins in a similar fashion. In this study it was desired to monitor each of 17 subjects daily during an ascent to $5400 \mathrm{~m}$ to determine what protein changes occurred and whether the changes occurred in advance of the clinical development of AMS.

It was also desired to study the relationship of proteinuria to AMS. Although proteinuria is well described in persons ascending to or dwelling at high altitude (Rennie et al., 1972) its diagnostic and prognostic value has not been clearly established.

\section{Materials and methods}

\section{Subjects}

The persons studied were the 17 members of the Birmingham Medical Research Expeditionary Society who have previously been discussed (Fletcher, 1979).

\section{Blood samples and urine collections}

Blood samples were collected each morning as previously described and the samples stored at $-80^{\circ} \mathrm{C}$ with solid $\mathrm{CO}_{2}$ during the trek and then at $-20^{\circ} \mathrm{C}$ until analysed. The urine samples comprised a 20-ml aliquot of a 24-hr urine collection stored (with $0.1 \%$ sodium merthiolate) at the ambient temperature for 4 weeks and then at $-20^{\circ} \mathrm{C}$ until analysed.

\section{Methods}

The packed cell volume (PCV) was measured as previously described (Howell and Cove, 1979). The total protein was measured by the method of Lowry et al. (1951). Immunoglobulin $G$ and C-reactive protein (CRP) were measured by radial immunodiffusion (Mancini, Carbonara and Heremans, 1965). Haptoglobin, orosomucoid, serum and urine albumin were measured by 'rocket' immunoelectrophoresis (Laurell, 1972). Both latter methods made use of Seward Immunostics antisera and reference sera (Seward Laboratory). Urine protein was also estimated using a urinary dipstick (BM-Test 8, Boehringer Manheim). The statistical analyses comprised means, standard error of the mean and Spearman's rank correlation coefficient. 
Results

Changes in plasma volume and protein concentration

The changes in plasma volume as measured by the alteration in the packed cell volume are shown in Fig. 1(b). The mechanism whereby this occurs has been discussed (Howell and Cove, 1979). Somewhat similar alterations occurred in the concentrations of the total serum protein (Fig. 1a). However, whereas the PCV returned to its original level of $43 \mathrm{~g} / \mathrm{l}$ on the 13 th day, the mean total protein concentration was still considerably elevated. The lower graph of Fig. 1 is the mean value of the total protein corrected for the percentage change in PCV. This suggests an early increase in the total circulating plasma protein which is maintained throughout the trek by a net synthesis of protein (see below). This assumes that there has been no alteration in red cell metabolism.

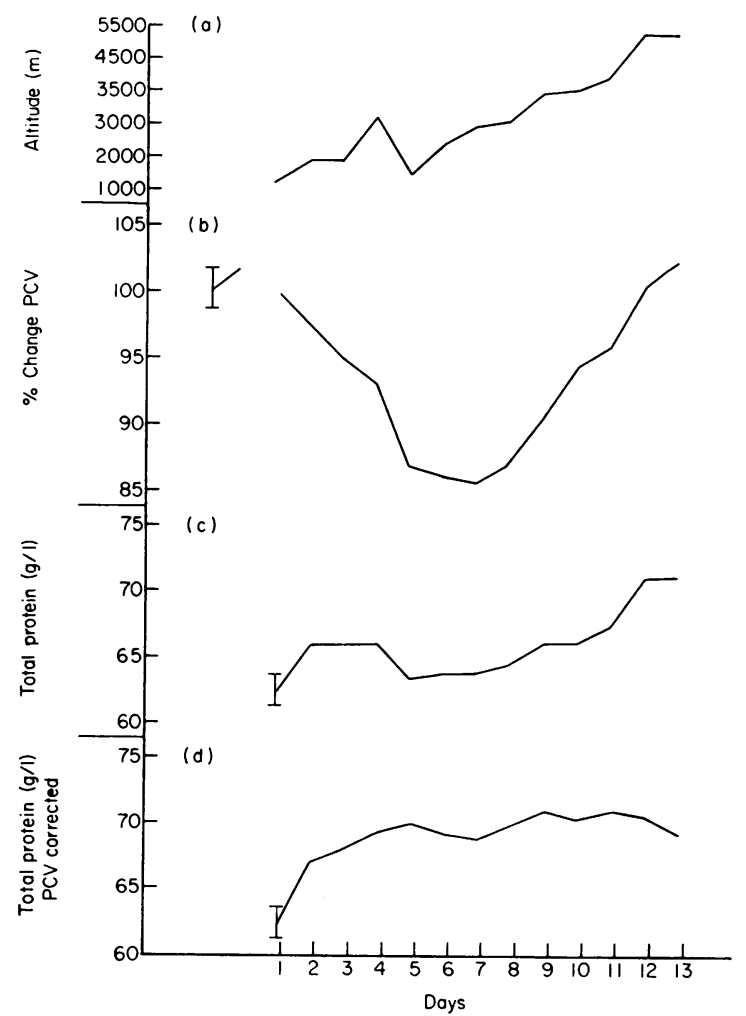

Fig. 1. The relationship between mean packed cell volume and total serum protein during the expedition. Representative error bars are shown.

Figure 2 ( $b$ and $d$ ) shows the changes that occurred in plasma albumin and immunoglobulin G. These 2 proteins comprise $70-80 \%$ of the total plasma proteins. Both proteins showed a decrease in concentration during the trek but this returned to

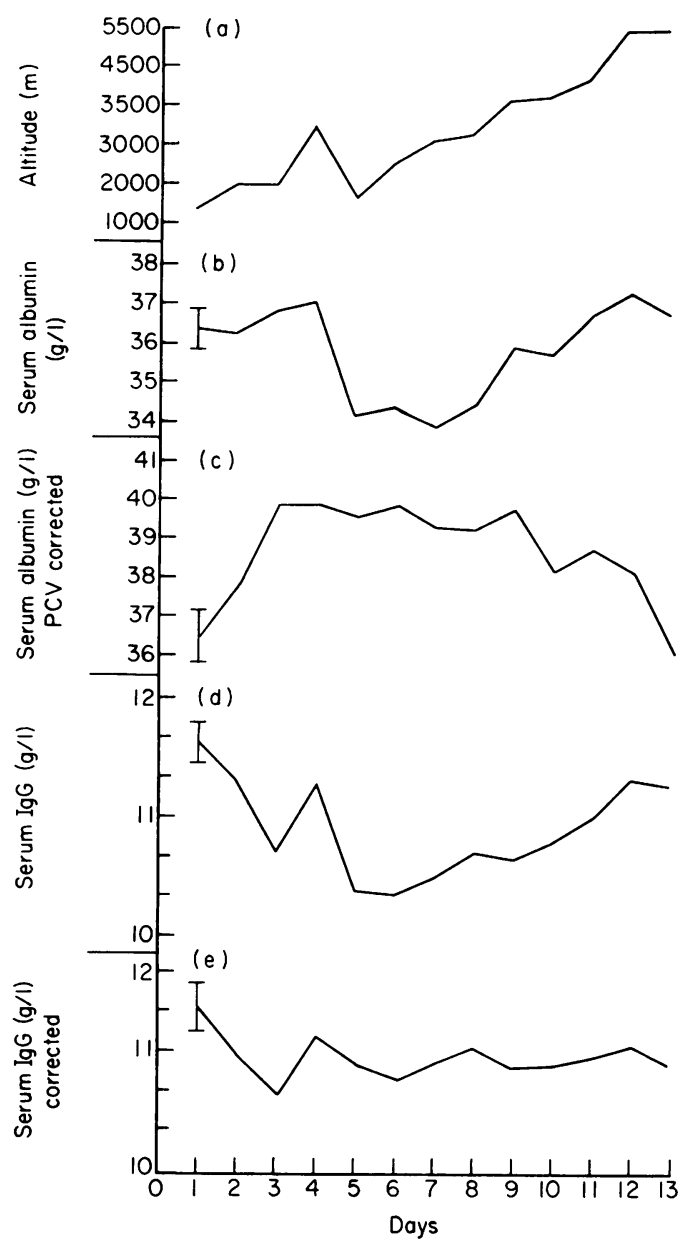

FIG. 2. The relationship between mean serum albumin, IgG and packed cell volume during the expedition. Representative error bars are shown.

normal by day 13 . When these changes are related to the PCV there is an apparent temporary increase in the total circulating plasma albumin (Fig. 2c) but little change in the IgG (Fig. 2e).

\section{Changes in the acute phase proteins}

All 3 proteins, haptoglobin, orosomucoid and CRP increased significantly in concentration during the trek, over and above any alterations in plasma volume. This change was opposite to that of the albumin and IgG and partially, at least, accounts for the increase in total protein (Fig. 1c).

Haptoglobin concentrations were $>150 \%$ above the initial values by the end of the trek (Fig. 3b). Significant degrees of haemolysis are associated 
with reduced haptoglobin (Fig. 3b) but this was apparent in only one subject whose haptoglobin concentrations were below his 3 control values taken before and after the trek, and below the lower limit of a normal population. These low values were probably due to a mild degree of 'march' haemolysis, although there was no detectable haemoglobinuria.

The orosomucoid concentrations paralleled haptoglobin, except that the subject with a low haptoglobin did not have a low orosomucoid concentration. CRP values increased approximately thirtyfold over base line values. This increase was greatest in the early part of the trek before high altitude was reached and before the occurrence of AMS (Fig. 3c).

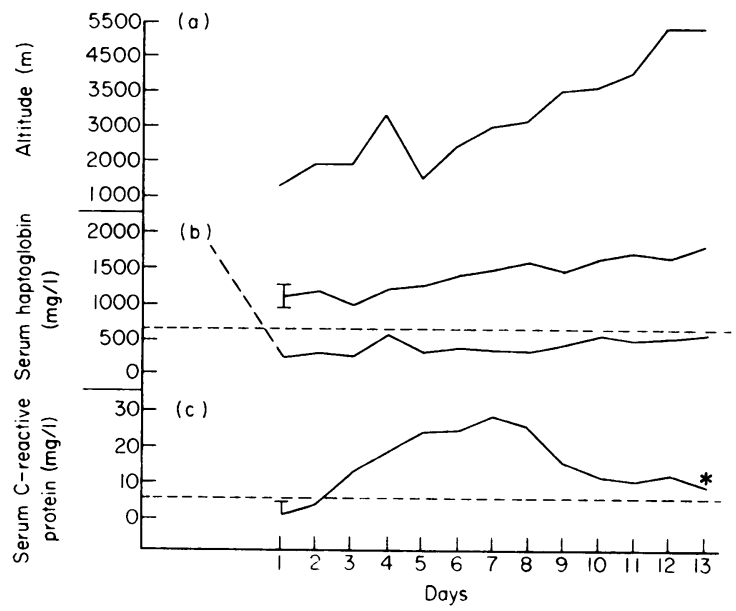

FIG. 3. Mean serum haptoglobin and C-reactive protein concentrations during the trek. Representative error bars are shown. One subject showed a marked reduction in haptoglobin (below $600 \mathrm{mg} / \mathrm{l}$ ) during the expedition.

\section{Proteinuria}

The dipstick test (BM-Test 8) of proteinuria showed that most subjects had a trace or slight proteinuria on one or more occasions but there was no relationship to altitude. This is demonstrated typically by subject 11 in the lower part of Fig. 4 . The dotted line indicates the sensitivity of the dipstick test. The subject showed slight proteinuria by dipstick on day 10 but none on all other occasions. All the albumin concentrations shown were measured by rocket immunoelectrophoresis (sensitivity $0.2 \mathrm{mg} / \mathrm{l}$ ). This more sensitive measurement shows that even trace albuminuria did not relate consistently to altitude in any one subject or in the group as a whole. Although protein excretion rates varied over $3500 \mathrm{~m}$ it appears to be haphazard.

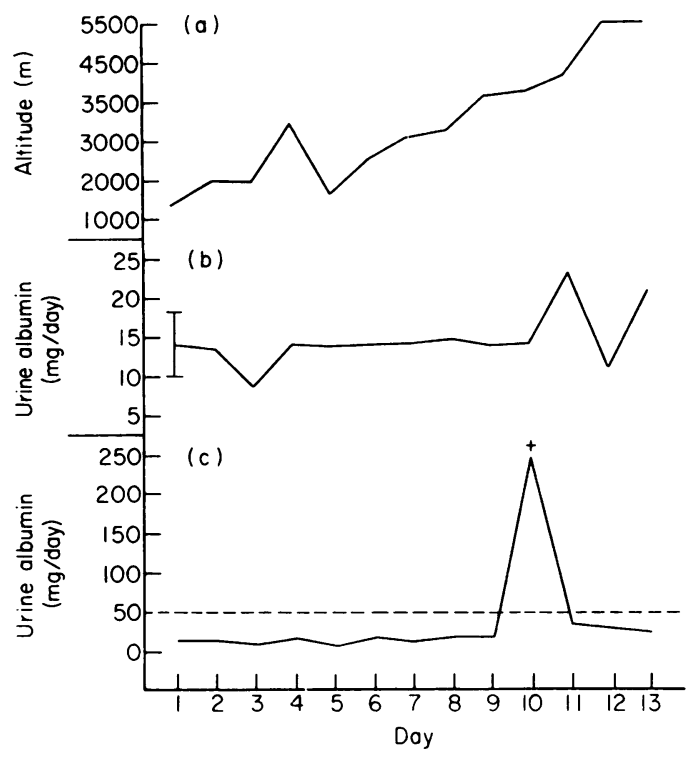

Fig. 4. (b) Mean 24-hr urine albumin concentrations during the trek with a representative error bar. (c) A subject who had one plus protein by urinary dipstick on day 10 . The dotted line is the sensitivity of the dipstick.

Relationship of the protein changes to acute mountain sickness

The 6 protein levels on each day were related to the degree of AMS suffered by the 17 subjects (Fletcher, 1979). Using Spearman's rank correlation coefficient none of the tests showed any correlation, except for CRP. On the 13th day the subjects who were clinically most affected by AMS had significantly higher concentrations of CRP $(P<0.05)$.

\section{Discussion}

Several authors have studied the changes in plasma proteins during acclimatization (Rennie et al., 1972; Hannon et al., 1969) and have documented changes in plasma volume and individual concentrations. Most of this work has been performed on fit persons, subjected to abrupt ascents by aeroplane. This study is different in several aspects.

1. A typical trek was undertaken, so that the value of any test could be judged in relation to the field situation.

2. It was wished to monitor serial changes that occurred in the tests whilst slowly ascending to altitude.

3. It was undertaken to determine whether any of these tests were of diagnostic or prognostic value in relationship to the development of AMS.

The results can be discussed under 3 headings. 


\section{Plasma volume changes}

The plasma volume changes that occurred caused marked alterations in the total protein, IgG and albumin. When these changes were related to the PCV a net shift of albumin into the circulation seemed to occur. This is entirely predictable when one considers that albumin (mol. wt 65 000) is free to move in and out of the vascular compartment and would presumably accompany any shift of water. IgG is a much larger molecule (mol. wt 150000 ) and would not be expected to parallel the movement of albumin although it would accompany water shifts to some extent. The red cells can be regarded as enormous molecules in this respect and, of course, do not move into or out of the vascular space. Therefore any change in the PCV must reflect plasma volume changes in the absence of significant haemolysis (see results), or increased haemopoiesis (Howell and Cove, 1979) as has been demonstrated. Other molecules would also accompany the water shifts, depending upon their molecular size, so that the concentration of an intravascular substance must be interpreted in the light of these changes.

\section{The acute phase proteins}

Haptoglobin, orosomucoid and CRP all increased highly significantly in concentration during the trek. The alterations in plasma volume are insufficient to account for such changes. However, the changes might be due to the 'ravages' of the trek, such as the muscular fatigue and bowel disorders. These problems tended to subside during the latter part of the trek and probably this is reflected by the gradual reduction in CRP concentrations. Haptoglobin and orosomucoid continued to rise throughout the trek but the mechanisms that switch the production of these proteins on and off is much slower than for CRP. All 3 proteins showed an increase in concentration that would indicate quite severe body stress during the early stages of the trek. The one subject with low haptoglobin concentrations presumably had a mild degree of 'march' haemolysis. This was apparent on the day of the first blood sample, possibly because he had walked many miles on the previous day. None of the daily serum protein concentrations correlated with the clinical degree of AMS except for the CRP on day 13 and, consequently, none was of use in the diagnosis or monitoring of the illness.

\section{Proteinuria}

Many authors have reported increased proteinuria at high altitude both in natives (Monge et al., 1969) and in people ascending rapidly to high altitude (Rennie et al., 1972). It has been suggested that this might be tubular proteinuria subsequent to renal hypoxia. The present results indicated that proteinuria was intermittent and slight, was unrelated to altitude or the degree of AMS, and was generally below the lower limit of detection by urine dipsticks. When increased proteinuria occurred it was not of tubular pattern as assessed by immune electrophoresis which agrees with previous findings (Rennie et al., 1972). The degree of proteinuria described by Pines (1978) was not confirmed. However, his study was on early morning urine samples which might have contained a greater concentration of protein.

\section{Acknowledgments}

We would like to thank Mr R. Holder, Mrs M. Peters and other members of the Wolfson Research Laboratories, Queen Elizabeth Medical Centre, for total protein and statistical analyses and Mr T. King and R. A. Crockson for the immunological measurements of the proteins.

\section{References}

Bradwell, A.R., Burnett, D., Ford, C. \& Newman, C. (1976) The prognosis of patients with carcinoma of the lung assessed by serum protein measurements. Clinical Science and Molecular Medicine, 53, 3P.

Fletcher, R.F. (1979) BMRES 1977 expedition: Signs and symptoms. Postgraduate Medical Journal, 55, 461.

Hannon, J.P., Chinn, K.S.K. \& ShieldS, J.L. (1969) Effects acute high altitude exposure on body fluid Federation Proceedings, 28, 1178.

Howell, A. \& Cove, D.H. (1979) BMRES 1977 expedition: The diuresis and related changes during a trek to high altitude. Postgraduate Medical Journal, 55, 471.

LAUrell, C.-B. (1972) Electroimmunoassay. Scandinavian Journal of Clinical and Laboratory Investigation, 29, (Suppl. 124), 21.

Lowry, O.H., Rosenbrough, N.J., Farr, A.L. \& Randall, R.J. (1951). Protein measurement with the folin phenol reagent. Journal of Biological Chemistry, 193, 265.

McConkey, B., Crockson, R.A. \& Crockson, A.P. (1972) An assessment of rheumatoid arthritis. Quarterly Journal of Medicine, 41, 115.

Mancini, G., Carbonara, A.O. \& Heremans, J.F. (1965). Immunochemical quantitation of antigens by single radial immunodiffusion. Immunochemistry, 2, 235.

Milford-Ward, A., Cooper, E.H., Turner, R., Anderson, J.A. \& Neville, A.M. (1977) Acute phase reactant protein profiles: an aid to monitoring large bowel cancer by CEA and serum enzymes. British Journal of Cancer, 35, 170.

Monge, C., Lozano, R., Marchena, C., Whittenbury, J. \& TORRES, C. (1969) Kidney function in the high altitude native. Federation Proceedings, 28, 1199.

Pines, A. (1978) High altitude acclimatization and proteinuria in East Africa. British Journal of Diseases of the Chest, 72, 196.

Rennie, D., Frayser, R., Gray, G. \& Houston, C. (1972) Urine and plasma proteins in men at $5400 \mathrm{~m}$. Journal of Applied Physiology, 32, 369. 